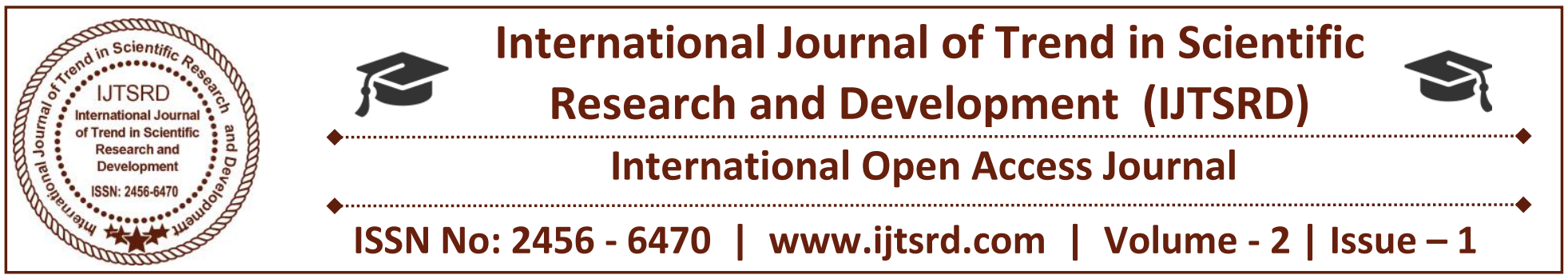

\title{
Labour-Management Relations in Manufacturing Industry A Case study on Uniparts India Ltd, Visakhapatnam District, A.P
}

\author{
Dr. Kantam Rajesh Kumar \\ Asst Professor, Dept of Public Administration, \\ B.T.College,Madanapalle, Chitoor
}

\begin{abstract}
Welfare of labour has vital significance for any country both from national and international point of view, the prosperity of the nation depends on the proper solutions of industry labour. The whole economic condition of the country depends upon increase of the productivity of labour and the management has to assume possible without an efficient labour force, capital investment better management, better technology the natural resources are the factors essential for production. However, everything proves meaningless until the labour power is added to all factors. In fact, workers are human beings are capable of holding responsibilities, extending co-operation for achieving objective. There have their own attributes and aspirations which if handled properly lead to the success of industries and growth of economy.
\end{abstract}

Labour welfare is very important in any sector of the organization for the future prospects. Industrial relations has become one of the most delicate and complex problems of modern industrial society. Industrial progress is impossible without cooperation of labour and harmonious relationships. Therefore, it is in the interest of all to create and maintain good relations between labour and employers management.

Industrial relation is defined as relation of Individual or group of employee and employer for engaging themselves in a way to maximize the productive activities. The field of industrial relations looks at the relationship between management and workers, particularly groups of workers represented by a union. Industrial relations are basically the interactions between employers, employees and the government, and the institutions and associations through which such interactions are mediated.

\section{Need for the study}

To know about the labour-management relations in the manufacturing industry through aspects like working conditions, safety levels, Coordination, motivation levels, encouragement and support between the labour and management in the manufacturing industry, Visakhapatnam District, Andhra Pradesh.

Specific Objectives of the study are

To analyse the labour- management relations in the manufacturing industry.

To examine the efforts made by the management in determining the decision regarding the performance of the employee.

To enumerate the role of management in providing the working conditions to the labour.

To explore the motivational levels provided by the management to the labour.

To identify the problems/bottlenecks in labour management relations in the manufacturing industry.

To recommend with few suggestions to strengthen labour management relations in the manufacturing industry for better performance. 


\section{District Profile}

Visakhapatnam (rural) is one of the 43 mandals in Visakhapatnam district of Andhra Pradesh in India. It is administered under Visakhapatnam revenue division and its headquarters are located at Visakhapatnam. The mandal lies on the coast of Bay of Bengal and is bounded by Bheemunipatnam, Anandapuram, Pendurthi, Gajuwaka and Pedagantyada mandals.

As of 2011 census, the mandal had a population of 260,192 . The total population constitute, 131,477 males and 128,715 females - a sex ratio of 979 females per 1000 males. 26,608 children are in the age group of 0-6 years, of which 13,486 are boys and 13,122 are girls a ratio of 973 per 1000 . The average literacy rate stands at $79.07 \%$ with 184,699 literates. Gopalapatnam (rural) is the most populated village and Bakkannapalem is the least populated village in the mandal.

\begin{tabular}{|l|l|ll|}
\hline Road Connectivity & $:$ & $\begin{array}{l}\text { A 4-lane Major District Road from Atcutapuram junction to Pudimadaka } \\
-3 \text { Kms from Atcutapuram junction. National Highway connectivity } \\
\text { from Atcutapuram junction to Anakapalle - 17 Kms. }\end{array}$ \\
\hline Port Connectivity & $:$ & $\begin{array}{l}\text { Visakhapatnam } \\
\text { Gangavaram Port - 30 Kms }\end{array}$ \\
\hline Air Conenctivity & $:$ & Visakhapatnam Airport - 40 Kms \\
\hline Rail & $:$ & Nearest Railway station - Anakapalle - 17 Kms. From APSEZ. \\
\hline
\end{tabular}

Andhra Pradesh Industrial Infrastructure Corporation Limited, an undertaking of Govt. of Andhra Pradesh, is a premier organization in the state, vested with the objective of providing Industrial infrastructure through development of Industrial Parks and Special Economic Zones. Over 320 Industrial Parks have been established throughout the State, covering an extent of over 1, 30,000 acres. The Industrial Parks and Special Economic Zones are playing a pivotal role, in attracting investments to the State both domestic \& foreign by providing multiple incentives. The Government's investor-friendly policies, state-of-theincentive schemes etc., make Andhra Pradesh a choicest destination for Industrial Investment, particularly in the manufacturing sector. art infrastructure, educated manpower, attractive

\section{Research Methodology}

To evaluate the labour management relations in the manufacturing industry. The survey was conducted with the help of structured interview questionnaires for employees on the basis of Random stratified sample.

$>$ The information has been collected from various books and Journals. In addition to the collected information through the above methods, substantial information was also collected through informal discussions with employees at all levels of the industry.

\section{Importance of manufacturing industries}

Manufacturing has emerged as one of the high growth sectors in India. Prime Minister of India, Mr Narendra Modi, had launched the 'Make in India' program to place India on the world map as a manufacturing hub and give global recognition to the Indian economy. India's ranking among the world's 10 largest manufacturing countries has improved by three places to sixth position in 2015. The Government of India has set an ambitious target of increasing the contribution of manufacturing output to 25 per cent of Gross Domestic Product (GDP) by 2025, from 16 per cent currently. India's manufacturing sector has the potential to touch US\$ 1 trillion by 2025 . There is potential for the sector to account for 25-30 per cent of the country's GDP and create up to 90 million domestic jobs by 2025. Business conditions in the Indian manufacturing sector continue to remain positive.

Uniparts is an Indian based global manufacturer of engineered systems and solutions. The Group is a leading supplier of systems and components for the off highway market and operate out of 8 locations in 3 countries with its products reaching over 25 countries 
worldwide. Uniparts has developed core competencies along the value chain like dual-shore manufacturing, warehousing solutions and an unparalleled supply chain capability. With strategic locations across the globe, Uniparts is able to service their Customers in all main markets like India, North and South America, Europe and Japan.

With extensive experience in the industry, backed by state of the art manufacturing technology and backward integrated manufacturing processes, Uniparts is able to support their customers with global solutions to meet their future challenges. Uniparts India has its Registered Office in New Delhi and manufacturing locations in Noida, Ludhiana \& Vishakhapatnam. The total work strength is over 3000 people and manufacturing space is over $45,000 \mathrm{Sq} / \mathrm{m}$. Uniparts India is a leading manufacturer and supplier of 3-point linkage solutions to the Indian market.

\section{Findings of the study:}

1. It is found from the analysis that most of the respondents not aware about Labour laws and policies.

2. Majority of the respondents have very less knowledge about rules and regulations of the industry.

3. It was found that most of the respondents noticed dissatisfaction about the safety and health conditions.

4. It was noticed that management should provide more initiative towards the implementation of welfare facilities.

5. Respondents were requested to provide updated training sessions for better functioning.

6. It is noticed that there is dissatisfaction towards the wages system and appraisal system.

7. The respondent says that the performance management is effectively formulated and implemented in the organization.

\section{Suggestions}

1. Management should create awareness to employees about the labour laws and procedures for their welfare.
2. There should be sufficient skill development training for the workers to be provided by the management.

3. Management should encourage to make delegation of authority to ensure speedy and

effective action.

4. Inculcating of proper work culture through humanization and personalization of management

5. Management should allow the labour to reveal the ideas for the growth of the industry and also develop communication in two way method.

6. Labour should communicate with the management about their problems related working conditions, safety issues and welfare activities in a cooperative manner.

7. Management need to be able to keep employees motivated if you want to get the best from them. This motivation should not only include praise for a job well done, but also some more tangible rewards.

8. Management should give opportunity to continue the employment of labour during production stoppages or slow-downs. When production is stopped or slowed by the absence of a key resource, such as missing material, broken equipment, or absent operators, production is interrupted.

\section{CONCLUSION}

Labour management is important because this is the backbone of any business and poor industrial relations can mean that productivity will be low and staff turnover will be high. If you want the most from your employees then it is vital that all consideration and care is put into good labor management.

The study examines the readiness for employee empowerment in different aspects, for management and labour to cooperate for the greater good of the enterprise. Labour-management teamwork can dramatically improve performance across many dimensions, including labour climate and job satisfaction. Labour groups and the organizations they work for will be rewarded if they work on improving the opportunities, constancy of purpose, and most importantly, the trust of each other. 


\section{REFERENCES}

1) A.M. Sharma, Industrial Relations, conceptual framework, Himalaya Publishing House, Mumbai, 2007.

2) C.B. Gupta, Human Resource Management, Sultan chand \& sons, New Delhi, 2007.

3) P. Subba Rao, Personnel \& Human Resource Management, Himalaya Publishing House, Mumbai, 2005

4) Rao, Human Resource Management, Excel books, New delhi,2001.

5) S.C.Srrivastava, Industrial Relations\& labour laws, Vikas publishing house ,New delhi,2005.

6) R.S.Davar, Personnel Management \& Industrial Relations, Vikas publishing house ,New delhi,2005. 